\title{
Detection of Mycobacterium paratuberculosis in raw cow's milk using polymerase chain reaction (PCR) technique
}

\author{
I.M. Ahmed ${ }^{1}$, R.A. Al-Sanjary ${ }^{2}$ and H.H. Al-Khazaly ${ }^{3}$ \\ ${ }^{1,3}$ Department of Microbiology, ${ }^{2}$ Department of Veterinary Public Health, College of Veterinary Medicine, University of \\ Mosul, Mosul, Iraq, Email: ${ }^{1}$ ihsanahmad1@yahoo.com, ${ }^{2}$ ralsanjary61@yahoo.com, ${ }^{3}$ haiffahussenalkazaly@gmail.com
}

(Received March 4, 2019; Accepted May 13, 2019)

\begin{abstract}
Paratuberculosis or Johne's disease is a chronic debilitating disease mainly infects ruminants and caused by Mycobacterium paratuberculosis. Previous serological studies in Mosul city confirm the presence of positive reactants for paratuberculosis in cattle. However, culture methods to confirm the disease need a long incubation period and also special media. Raw cow's milk is considered as potential source for transmission of M. paratuberculosis in cows' herds. Accordingly, this study aimed to detect the presence of $M$. paratuberculosis specifically in the raw cow's milk using polymerase chain reaction (PCR) technique as a rapid, sensitive and reliable method. A total of 50 samples of raw cow's milk were collected from cows suffering from emaciation and unresponsive to antibiotic treatment. All the samples were subjected to DNA extraction and direct amplification PCR. The results showed that $3(6 \%)$ out of 50 milk samples were positive for $M$. paratuberculosis. This is the first study in Mosul city that confirms the presence of M. paratuberculosis in raw cow's milk using PCR technique. In conclusion, raw cow's milk could be an important source for M. paratuberculosis infection in dairy cows, and also PCR technique could be helpful in rapid diagnosis of paratuberculosis.
\end{abstract}

Keywords: Mycobacterium paratuberculosis, PCR, Cow's milk, Johne's disease

Available online at http://www.vetmedmosul.com, (C) 2020, College of Veterinary Medicine, University of Mosul.

This is an open access article under the CC BY 4.0 license (http://creativecommons.org/licenses/by/4.0/).

$$
\begin{aligned}
& \text { الكشف عن العصيات نظيرة السل في حليب الأبقار الخام باستخدام تقنية تفاعل البلمرة المتسلسل } \\
& \text { إحسان منير احمد'، رعد عبدالغني بثير' و هيفاء حسين الذزعلي' } \\
& \text { 'فرع الأحياء المجهرية، `فرع الصحة العامة البيطرية، كلية الطب البيطري، جامعة الموصل، الموصل، العراق }
\end{aligned}
$$

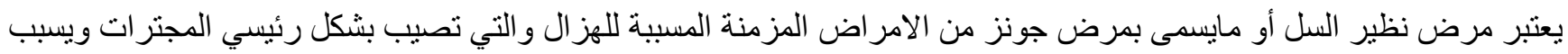

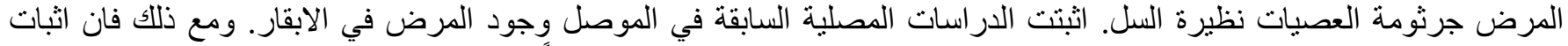

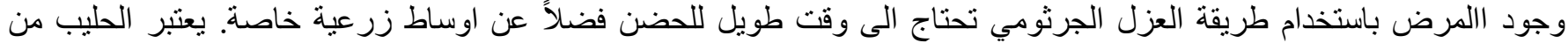

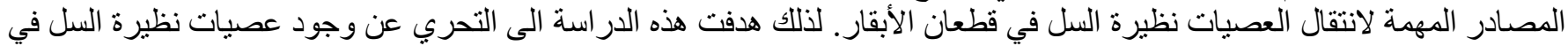

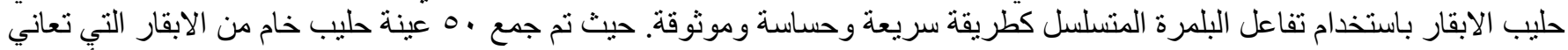

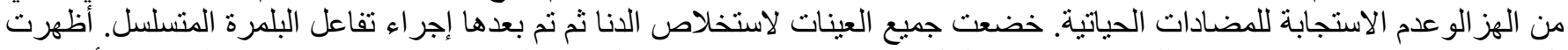

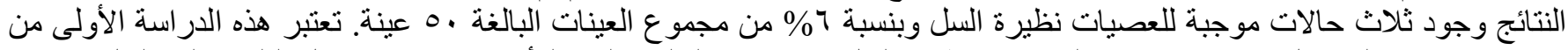

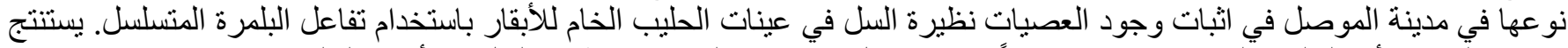
من هذ الدر اسة أن الحليب الخام قد يكون مصدر أ مهما لانتقال الاصفابة بالعصيات نظيرة السل في أبقار الحليب، كما وان استخدام تقنية تفاعل البلمرة المتسلسل يساعد في التشخيص السريع لمرض نظير السل السن. 


\section{Introduction}

Mycobacterium paratuberculosis is the causative agent of paratuberculosis (Johne's disease), a chronic wasting disease, which mainly infects ruminants and can frequently, be found in dairy cattle $(1,2)$. The disease has worldwide distribution and leads to reduce milk yield of the affected herds and contribute to economic loss (2-4). The bacteria are mainly shedding through feces of the infected cattle (5). However, the milk also considers as an important source of infection for the other animals (6). Many studies are confirming the role of raw milk and colostrum as a potential source of infection $(6,7)$. The gold standard method for diagnosis of paratuberculosis is bacterial culture. However, this method is cumbersome and timeconsuming, and cultured samples may need up to 3 months to consider negative (7). Therefore, the diagnosis is mainly relied on serological (8-10) and molecular methods $(6,7,11,12)$. Paratuberculosis has been confirmed previously in several studies in Iraq. A previous preliminary study in Mosul city, Iraq confirmed the presence of seropositive antibodies against $M$. paratuberculosis in different ruminant's species including sheep (10), goats (13) and cattle (9) using enzyme-linked immunosorbent assay (ELISA). Another recent study in 2018 by Al-Farwachi and colleagues (14) confirm the presence of antibodies against $M$. paratuberculosis by ELISA in both diarrheic and nondiarrheic or apparently healthy cattle that brought to the Veterinary Teaching Hospital of College of Veterinary Medicine, Mosul University, Mosul, Iraq. Molecular methods offer rapid sensitive techniques for the diagnosis of paratuberculosis. Hence, the use of polymerase chain reaction as a molecular method can help in rapid detection of $M$. paratuberculosis in different types of samples $(6,7,15,16)$, and offer a rapid diagnosis of the disease. Accordingly, this study aimed to detect the presence of $M$. paratuberculosis in raw cows' milk in Mosul city using PCR technique.

\section{Materials and methods}

\section{Sample collection}

Total of 50 samples of raw cow's milk was collected from cows suffering from emaciation, unresponsive to antibiotic treatment and retreating at Veterinary Teaching Hospital, College of Veterinary Medicine, University of Mosul, during the period of May to July 2018. A volume of $10 \mathrm{ml}$ of milk was collected in a sterile test tube and transported to the Research Laboratory, Department of Veterinary Public Health, College of Veterinary Medicine. The samples were stored at $-20{ }^{\circ} \mathrm{C}$ until being used for the DNA extraction process. For the preparation of samples, 10 $\mathrm{ml}$ of each milk sample was centrifuged at $3000 \times \mathrm{g}$ for 15 min. The supernatant was discarded and the pellet was resuspended in $100 \mu \mathrm{l}$ of saline solution (17).

\section{DNA extraction}

Mycobacterium paratuberculosis DNA was extracted using a commercial DNA extraction kit (Mycobacterium paratuberculosis Vet, Ref: VET-36, Sacace Biotechnology, Italy). According to manufacturer instructions, $1.5 \mathrm{ml}$ Eppendorf tubes were prepared according to the number of tested samples. Each tube contains $50 \mu$ of milk sample, 20 $\mu \mathrm{l}$ of internal control and $50 \mu \mathrm{l}$ of negative control of extraction. Additionally, $50 \mu \mathrm{l}$ of negative control was added to a separate tube as negative control. $300 \mu \mathrm{l}$ of lysis solution was added to each tube and vortexed and incubated for $5 \mathrm{~min}$ at $65^{\circ} \mathrm{C}$. All tubes were centrifuged for $30 \mathrm{sec}$ at $8000 \times g$. The supernatant was carefully removed without disturbing the pellet. After that, $300 \mu \mathrm{l}$ of washing solution 1 was added to each tube, then vortexed vigorously and centrifuged for $30 \mathrm{sec}$ at $8000 \times \mathrm{g}$. The supernatant was discarded and $500 \mu \mathrm{l}$ of washing solution 2 was added to each tube and vortexed vigorously and centrifuged for 30 sec at $8000 \times g$. The supernatant was discarded and the pellet was resuspended in $50 \mu \mathrm{l}$ of DNA-eluent and incubated for $5 \mathrm{~min}$ at $65{ }^{\circ} \mathrm{C}$ and vortexed periodically. After that, the tubes were centrifuged for $1 \mathrm{~min}$ at a maximum speed of $16000 \times g$, and the supernatant contains purified DNA was kept at $-20^{\circ} \mathrm{C}$ for PCR assay.

\section{Amplification and gel electrophoresis}

The amplification of the target $M$. paratuberculosis gene was performed according to the manufacturer instruction (Mycobacterium paratuberculosis Vet, Ref: VET-36, Sacace Biotechnology, Italy). Briefly, PCR-mix1 tubes were prepared and $10 \mu \mathrm{l}$ of PCR-mix-2 was pipetted into each PCR-mix-1 tube. Then, $10 \mu \mathrm{l}$ of extracted DNA was added to the corresponding tubes. For the negative control tube, $10 \mu \mathrm{l}$ of DNA buffer was added. Additionally, for positive control tube, $10 \mu \mathrm{l}$ of positive control (diluted 1:10 with DNA buffer) was added. The PCR was performed using Eppendorf Thermocycler (Eppendorf, Germany) with one cycle at $95{ }^{\circ} \mathrm{C}$ for $2 \mathrm{~min}, 42$ cycles consisting of (step 1: $95{ }^{\circ} \mathrm{C}$ for $1 \mathrm{~min}$, step 2: $66^{\circ} \mathrm{C}$ for 1 $\min$, step 3: $72{ }^{\circ} \mathrm{C}$ for $1 \mathrm{~min}$ ). Then, one cycle at $72{ }^{\circ} \mathrm{C}$ for 1 min was set for final extension. Finally, the reactions were cooled at $10^{\circ} \mathrm{C}$ until proceeding to the gel electrophoresis. Analysis of results was based on the presence of specific bands of amplified gene using $2 \%$ agarose gel stained with ethidium bromide (Amersham Bioscience, USA), and visualized using UV transilluminator and digital camera. The presence of specific amplified DNA fragment with209 bp indicating a positive result for $M$. paratuberculosis, in addition, internal control with a product size of $700 \mathrm{bp}$ must also appear to ensure that the extraction was valid. 


\section{Results}

The results showed that only 3 out of 50 milk samples were positive and the incidence rate was $6 \%$. PCR products with a size of $209 \mathrm{bp}$ were detected in all positive samples. In addition, internal control bands were also detected with product size of $700 \mathrm{bp}$, indicating successful DNA extraction as shown in Figure (1).

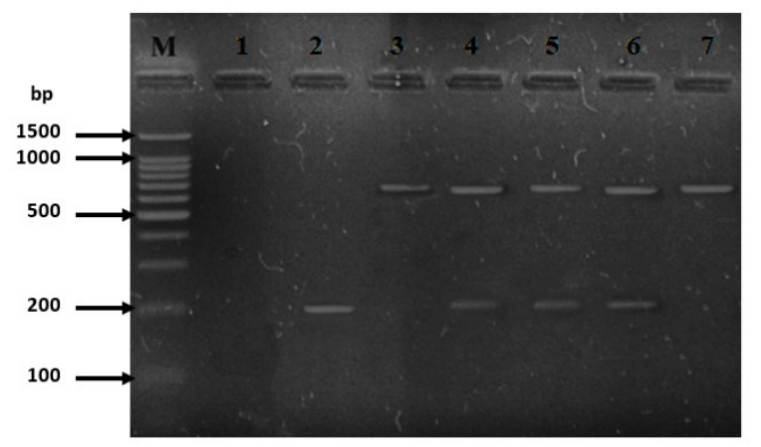

Figure 1: Result of DNA amplification of $M$. paratuberculosis electrophoresed on 2\% agarose gel stained with ethidium bromide. Lane M: DNA Ladder, lane 1: negative control, lane 2: positive control, lanes 4,5 and 6 are positive milk samples with 209 bp product size, lanes 3 and 7 are negative milk samples for M. paratuberculosis.

\section{Discussion}

Paratuberculosis has gained great importance worldwide due to severe economic losses $(3,4)$. The disease mainly affects ruminants including cattle, sheep and goats, and causes chronic contagious enteritis that characterized by unresponsive to treatment $(18,19)$. Recent studies in Mosul city referred to the presence of seropositive reactant against M. paratuberculosis in sheep, goats and cattle which give evidence of the importance of the disease in ruminant $(9,10,13,14)$. In this study, M. paratuberculosis was detected in (6\%) 3/50 of tested cow's milk, which indicates direct shedding of the pathogen in the raw milk. Since paratuberculosis is a chronic disease and clinical signs may only appear after years of infection, the secretion of $M$. paratuberculosis in milk is considered as main risk factor for transmission and spreading of the disease to calves $(6,11,20,21)$. In addition, the zoonotic potential of $M$. paratuberculosis via consumption of contaminated milk and milk products is of public health importance due to frequent isolation of $M$. paratuberculosis from Crohn's disease patients (22-25). The PCR used in our study offer sensitive and rapid method for detection and confirmation of the presence of $M$. paratuberculosis in clinical samples $(6,7,11)$. Unlike, culture method that requires special media and experienced personnel, PCR might be conducted in few hours in the equipped laboratory, while culture method might need several months to consider negative results $(6,7,25,26)$. The PCR technique allowed the detection of fewer M. paratuberculosis cells in $2 \mathrm{~mL}$ of milk, making this procedure is rapid, sensitive and cost-effective for the diagnosis of clinical and subclinical paratuberculosis $(11,27)$. In a study targeting cattle population in south of Iraq 29/81 (35.8\%) were positive for M. paratuberculosis using PCR from buffy coat of seropositive cows detected by ELISA, and this highlighted the importance of PCR as a confirmatory tool (28). Another study in Brazil, $M$. paratuberculosis was detected in $20(16.5 \%)$ out of 121 of milk samples using conventional PCR (29). Another study in Cyprus confirms the presence of M. paratuberculosis in $63(28.6 \%)$ positive samples out of 220 milk samples collected from milk storage (25). However, in our study the lower number of positive samples compared with these studies may be due to sporadic cases that have been received in our Veterinary Teaching Hospital rather than detection of infected farms.

\section{Conclusion}

In conclusion, $M$. paratuberculosis was detected successfully in raw cow's milk using PCR which indicates the significance of milk as a potential source of infection in dairy cows.

\section{Acknowledgments}

This study was supported by the College of Veterinary Medicine, University of Mosul, Mosul, Iraq.

\section{References}

1. McAloon CG, Roche S, Ritter C, Barkema HW, Whyte P, More SJ, O'Grady L, Green MJ, Doherty ML. A review of paratuberculosis in dairy herds-Part 1: Epidemiology. Vet J. 2019;246:59-65. https://doi.org/10.1016/j.tvj1.2019.01.010

2. Salem M, Heydel C, El-Sayed A, Ahmed SA, Zschöck M, Baljer G. Mycobacterium avium subspecies paratuberculosis: An insidious problem for the ruminant industry. Trop Anim Heal Prod. 2013;45:351-66. https://doi.org/10.1007/s11250-012-0274-2

3. Kirkeby C, Græsboll K, Nielsen SS, Toft N, Halasa T. Epidemiological and economic consequences of purchasing livestock infected with Mycobacterium avium subsp. paratuberculosis. BMC Vet Res. 2017;13:202. https://doi.org/10.1186/s12917-017-1119-z

4. Hasonova L, Pavlik I. Economic impact of paratuberculosis in dairy cattle herds: A review. Vet Med. 2006;51:193-211.

5. Foddai A, Strain S, Whitlock RH, Elliott CT, Grant IR. Application of a peptide-mediated magnetic separation-phage assay for detection of viable Mycobacterium avium subsp. paratuberculosis to bovine bulk tank milk and feces samples. J Clin Microbiol. 2011;49:2017-9. https://doi.org/10.1128/JCM.00429-11

6. Khol JL, Braun AL, Slana I, Kralik P, Wittek T. Testing of milk replacers for Mycobacterium avium subsp. paratuberculosis by PCR and bacterial culture as a possible source for Johne's disease 
(paratuberculosis) in calves. Prev Vet Med. 2017;144:53-6. https://doi.org/10.1016/j.prevetmed.2017.05.013

7. Laurin E, McKenna S, Chaffer M, Keefe G. Sensitivity of solid culture, broth culture, and real-time PCR assays for milk and colostrum samples from Mycobacterium avium ssp. paratuberculosisinfectious dairy cows. J Dairy Sci. 2015;98:8597-609. https://doi.org/10.3168/jds.2014-8758

8. Correa-Valencia NM, Ramírez NF, Olivera M, Fernandez-Silva JA. Milk yield and lactation stage are associated with positive results to ELISA for Mycobacterium avium subsp. paratuberculosis in dairy cows from Northern Antioquia, Colombia: A preliminary study. Trop Anim Heal Prod. 2016;48:1191-200. https://doi.org/10.1007/s11250016-1074-x

9. Al-Aalim AM. Serological detection of johne's disease in cattle using ELISA techniques. Tikrit J Pure Sci. 2010;15:37-9.

10. Ahmed IM. Serodiagnosis of Johne's disease by indirect ELISA in ovine. Iraqi J Vet Sci. 2010;24:41-3. https://doi.org/10.33899/ ijvs.2010.5576

11. Gilardoni LR, Fernandez B, Morsella C, Mendez L, Jar AM, Paolicchi FA, Mundo SL. Mycobacterium paratuberculosis detection in cow's milk in Argentina by immunomagnetic separation-PCR. Brazilian J Micobiol. 2016;47:506-12. http://dx.doi.org/10.1016/j.bjm.2016.01. 013

12. Dzieciol M, Volgger P, Khol J, Baumgartner W, Wagner M, Hein I. A novel real-time PCR assay for specific detection and quantification of Mycobacterium avium subsp. paratuberculosis in milk with the inherent possibility of differentiation between viable and dead cells. BMC Res Notes. 2010;3:251. https://doi.org/10.1186/1756-0500-3251

13. Al-Kass AM. Seroprevalence of Johne's disease in goats. Iraqi J Vet Sci. 2009;23:281-3.

14. Al-Farwachi M, Al-Jubory K, Flayyih A. Prevalence of paratuberculosis amange cattle with diarrhea in Ninavah, Iraq. Res Opin Anim Vet Sci. 2018;8:1-3.

15. Yue R, Liu C, Barrow P, Liu F, Cui Y, Yang L, Zhao D, Zhou X. The isolation and molecular characterization of Mycobacterium avium subsp. paratuberculosis in Shandong province, China. Gut Pathol. 2016;8:9. https://doi.org/10.1186/s13099-016-0092-6

16. Timms VJ, Mitchell HM, Neilan BA. Optimisation of DNA extraction and validation of PCR assays to detect Mycobacterium avium subsp. paratuberculosis. J Microbiol Meth. 2015;112:99-103. https://doi.org/10.1016/j.mimet.2015.03.016

17. Al-Sanjary RA, Mohammed HA, Dahl MO. Using polymerase chain reaction technique (PCR) for detection Brucella melitensis in aborted ewes' milk in Nineveh, Iraq. Assiut Vet Med J. 2014;60:140.155-9.

18. Dimareli-Malli Z. Detection of Mycobacterium avium subsp. paratuberculosis in milk from clinically affected sheep and goats. Inter J Appl Res Vet Med. 2010;8:44-50.

19. Hafiz NM, Saad MF, Hanafy MH, Abdel-Latif EF. Detection of Mycobacterium avium subsp. paratuberculosis in raw buffaloe's milk. Inter J ChemTech Res. 2016;9:123-8.
20. De Albuquerque PPF, de Souza Santos A, de Souza Neto OL, Kim PdCP, Cavalcanti EFTSF, de Oliveira JMB, Mota RA, Júnior JWP. Detection of Mycobacterium avium subsp. paratuberculosis in bovine milk from the state of Pernambuco, Brazil. Brazilian J Microbiol. 2017;48:113-7. http://dx.doi.org/10.1016/j.bjm.2016.10.010

21. Shrafati-chaleshtori F, Sharafati-chaleshtori R, Shakerian A, Momtaz $\mathrm{H}$. Detection of Mycobacterium paratuberculosis using polymerase chain reaction (PCR) in cow raw milk samples in shahre-kord. Med Lab J. 2009;3:1-5.

22. Singh AV, Singh SV, Singh PK, Sohal JS. Is Mycobacterium avium subsp. paratuberculosis, the cause of Johne's disease in animals, a good candidate for Crohn's disease in man? Indian J Gastroenterol. 2010;29:53-8. https://doi.org/10.1007/s12664-010-0019-y

23. Zarei-Kordshouli F, Geramizadeh B, Khodakaram-Tafti A. Prevalence of Mycobacterium avium subspecies paratuberculosis IS 900 DNA in biopsy tissues from patients with Crohn's disease: Histopathological and molecular comparison with Johne's disease in Fars province of Iran. BMC Infect Dis. 2019;19:23. https://doi.org/10.1186/s12879018-3619-2

24. McAloon CG, Roche S, Ritter C, Barkema HW, Whyte P, More SJ, O'Grady L, Green MJ, Doherty ML. A review of paratuberculosis in dairy herds-Part 2: On-farm control. Vet J. 2019;246:54-58. https://doi.org/10.1016/j.tvj1.2019.01.009

25. Slana I, Liapi M, Moravkovaa M, Kralovaa A, Pavlika I. Mycobacterium avium subsp. paratuberculosis in cow bulk tankmilk in Cyprus detected by culture and quantitative IS900 and F57 realtime PCR. Preve Vet Med. 2009;89:223-6. https://doi.org/10.1016/j.prevetmed.2009.02.020

26. Mortier RA, Barkema HW, De Buck J. Susceptibility to and diagnosis of Mycobacterium avium subspecies paratuberculosis infection in dairy calves: a review. Preve Vet Med. 2015;121:189-98. https://doi.org/10.1016/j.prevetmed.2015.08.011

27. Stabel J, Bradner L, Robbe-Austerman S, Beitz D. Clinical disease and stage of lactation influence shedding of Mycobacterium avium subspecies paratuberculosis into milk and colostrum of naturally infected dairy cows. J Dairy Sci. 2014;97:6296-304. https://doi.org/10.3168/jds.2014-8204

28. Kawther KJ, Fawziah AA, Rasha MO. Diagnostic application of ELISA and IS900PCR using buffy coat as a source sample for the detection of Mycobacterium avium subspecies paratuberculosis in subclinical cases of bovine paratuberculosis. Basrah J Vet Res. 2018;17:186-95

29. Carvalho I, Silva Jr A, Campos V, Moreira M. Detection of Mycobacterium avium subspecies paratuberculosis by polymerase chain reaction in bovine milk in Brazil. J Dairy Sci. 2009;92:5408-10. https://doi.org/10.3168/jds.2008-1816 